\title{
Professional Education, Internships and Supervision: Persistent challenges and impasses
}

Education in social service has been a constant object of concern and debate, and its contours have been determined by the historic conjunctures and the action of subjects guided by professional projects on distinct ethical and political planes. Thus, to consider professional education, especially internships and their supervision, involves recognizing the trajectory that allows conceiving these internships as a continuum between undergraduate studies, graduate work, permanent education, professional practice and political organization of social workers (ABEPSS, 2008).

Historically, it can be observed that until the 1970s the dynamic of professional education was based on a symmetrical relationship between educational institutions and the fields of internships, with a focus on professional action and an emphasis on technical and instrumental aspects. In this dynamic there was a synergy between professors and field supervisors, in relation to the concept of the profession, the contents and practices that compose professional education and to needs for knowledge. It is not by chance that there have been many studies about supervision in social work in this period, revealing the intrinsic articulation between the hegemonic social project and the institutional projects incorporated by the professional category. This articulation, allied to social workers condition as the front line executors of social policies, had repercussions on the convergence between what students should learn to be able to exercise the profession and that which was practiced within institutions. In this context, internships were conducted in complete harmony among the actors involved, given that the objective was to execute what was learned. The education of social workers was shared between the educational institution and the institutions where internships were conducted, which were made responsible for teaching through practice. This design presupposed systematic supervision of social workers as an essential attribution for making professional education concrete. The synchronicity was strengthened by the systematic spaces of discussion, which reiterated the hegemonic professional and social project of the time, anchored in the technical and political competence of the supervisors and professors.

This virtuous circle began to be broken as a consequence of three intrinsically related facts: the new form of considering the profession; the entrance of the majority of schools of social work into federal universities; and the recognition of social work as a field of knowledge by the national agencies that provide financial support to research and graduate studies.

The new form of thinking of the profession, based on a critical-dialectical perspective, revealed the inseparability between the three dimensions that sustain it: theoretical-methodological, ethical-political and technical-operative. The adoption of a perspective of knowledge that would articulate the historic and theoreticalmethodological perspective became imperative, both for the development of the profession and for professional education. Thus, an aspiration arose to educate professionals who understood their practice and understood themselves within the context of social life, and therefore, the relations of their practices with the totality of the historic process became a central issue (ABESS, 1989).

The entrance of the majority of schools of social work - which until then had been maintained mostly by religious organizations - into university structures took place in the 1970s, during the military dictatorship. At this time, higher education policy reorganized the administrative and curricular structures of universities. This involved the incorporation of schools that supported the development project adopted by the country at the time. An example of this was the expansion of schools of law and administration, among others, as well as the inclusion in curriculums of disciplines such as The Study of Brazilian Problems, which sought to strengthen the ideology of national security. The incorporation of the schools of social service imposed distinct parameters for their recognition in the academic realm, such as the demand for articulation of the tripod of education, research and extension, which had decisive impacts on the teaching career of social workers. Universities favored an 
interdisciplinary environment that required professors to maintain a theoretical competence consistent with their recognition in academic space. Contrary to what the dictatorship expected from university reform, universities became important spaces for the continuity of the political debate, both in relation to a social project that was different from that proposed by the government and also in relation to the debate about a new concept for the profession. Nevertheless, the concentration of efforts over the years to develop the theoretical-methodological and ethical dimensions of the new professional profile committed to the values of liberty and equality, and to consolidate social work as a field of knowledge, was equally committed to the debate about the technicaloperative dimension of the profession. This had strong repercussions on curricular internships and their supervision. In other terms, a distance was established, to a large degree, between field supervisors and academic supervisors, between internship institutions and educational institutions. Some ill-advised analyses attribute this process to a well-known criticism: that theory becomes different in practice. These issues have repercussions beyond the educational process, in professional practice, and have been promoted, since the 1990s, by finance agencies and inspection commissions of the Federal Social Work Council (CFESS), related to the competencies and attributions particular to social workers.

The organization of social work as a field of knowledge, which is a result of the development of the profession and its insertion in the university realm at an undergraduate and graduate level, was essential to give legitimacy to the profession in the realm of production of knowledge. It also provided greater theoreticalmethodological density to knowledge produced about the profession, about the reality where it operates and about intervention itself. This production is constructed and sustained in a new ethical-political project and guarantees political insertion, supported by critical social theory, in the Brazilian scene. The apprehension of professional demands based on a set of social relations was of great importance to the educational realm of the profession, allowing it to go beyond an immediate, pragmatic and self-circumscribed apprehension. The academic production in this new perspective provided important support to understanding the reality of professional practice and to redirect it.

In this new configuration, the proposal for professional education was transformed, deeply altering the nature of supervised internships. If these internships previously took place under a convergence between educational and practical institutions, the new proposal, by defending a certain social project, confronted the field institutions of the internship, and tensions arose between the main actors involved in the educational process. Contrary to what took place in other professions that conduct interventions, a high degree of responsibility continued to be given in the educational process to field institutions of internships. In this way, internships and their supervision, which was shared by field supervisors and academic supervisors, became permeated by conflicts intrinsic to differing projects, raising problems that were confronted in the supervision process. This new situation required concentrated efforts from the profession to face the challenges that were presented, given that it is the locus at which the questions of daily professional practice gain contours and visibility.

The field of the internship came to express one of the main impasses in the educational process. On one hand, field supervisors predominantly base their actions and guidelines on institutional demands. On the other, the academy emphasizes the implementation of a professional project, which is now hegemonic within the professional category, which proposes changes in the institutional and social order. The conviviality between distinct logics requires knowledge that allows undertaking mediations, to guarantee the critical education of students in concrete and contradictory spaces.

Another contradiction is the difficult articulation between the distinct ethical-political professional projects and the actors involved with internship supervision. The impasses become visible solely when concrete situations are analyzed and proposals are presented. A failure to explain differences is recurrent. For a wide variety of reasons, the masking of these differences makes it difficult to construct the professional profile now proposed for the profession. This situation is aggravated in the current conjuncture due to a growing dissociation between the professional ethical-political project and a national project diametrically opposed to the universalization and guarantee of rights.

These issues have gained visibility as objects of studies and debates by researchers who have been problematizing internships and their supervision. It is hoped that this movement produces innovative responses that make concrete the desire expressed by professor Iamamoto (1992, p. 203) to "prepare the student to handle the small questions of daily practice as great intellectual and operational challenges".

Beyond the particular theme addressed, this edition of Revista Katálysis has a special appeal for two reasons: the first is that the articles address antagonisms, challenges and particularities of the field of internship and supervision in the process of professional education. The second reason is that the authors are from different regions and have various approaches, thus encouraging an expansion of the debate.

Regina Célia Mioto and Vera Nogueira, October 2016. 


\section{References}

ASSOCIAÇÃO BRASILEIRA DE ENSINO DE SERVIÇO SOCIAL (ABESS). A metodologia no serviço social. Cadernos ABESS. N. 3. São Paulo: Cortez Editora, 1989. 191 p.

ASSOCIAÇÃO BRASILEIRA DE ENSINO E PESQUISA EM SERVIÇO SOCIAL (ABEPSS). Estatuto da associação brasileira de ensino e pesquisa em serviço social. Disponível em: http://www.abepss.org.br/uploads/textos/arquivo_201604041530365473870.pdf. Acesso em: 15 set. 2016.

IAMAMOTO, M. V. Renovação e conservadorismo em Serviço Social. São Paulo: Cortez, 1992.

\section{Regina Célia Mioto}

regina.mioto@gmail.com

Doutora em Saúde mental pela Universidade Estadual de Campinas (UNICAMP)

Professora da Universidade Católica de Pelotas (UCPel)

\section{Vera Maria Ribeiro Nogueira}

veramrn@gmail.com

Doutora em Enfermagem pela Universidade Federal de Santa Catarina (UFSC)

Professora da Universidade Católica de Pelotas (UCPel)

\section{UCPel}

R. Gonçalves Chaves, 373, Centro

Pelotas - Rio Grande do Sul - Brasil

CEP: 96015-560 